\title{
O crime na fronteira e os limites da justiça no Brasil meridional - segunda metade do século XIX
}

\section{Crime in the borderland and the limits of justice in the southern Brazil - second half of the nineteenth century.}

Mariana Flores da Cunha Thompson Flores Universidade Federal de Santa Maria

Recibido: $13 / 02 / 2017$

Aceptado: 28/05/2017

Resumo. A incidência da fronteira na prática de crimes não se restringe a crimes como contrabando, explicitamente um crime de fronteira, mas se faz sentir nos mais variados tipos de crimes como um elemento estratégico nas ações dos sujeitos que se valiam da incoerência inerente a esse espaço, decorrente da justaposição de soberanias e leis distintas, para manejar suas brechas. A ação da fronteira é verificável em vários âmbitos da vida dos fronteiriços, legais ou não, e tanto o cometimento de crimes, quanto o cumprimento da lei e a ação do estado, ganham configurações peculiares nesse espaço. A fuga pela fronteira, que coloca o infrator sob outra jurisdição a qual não compete puni-lo, é justamente a grande possibilidade de estratégia que a fronteira oferece. Através da análise dos crimes de contrabando, roubo de gado e processos de sedução de escravos e manutenção de posse e liberdade abordaremos os referidos aspectos desse espaço limítrofe.

Palavras chave: Fronteira. Crime. Lei.

\begin{abstract}
The incidence of the border on the practice of crimes is not restricted to crimes like contraband, explicitly a border crime, but is felt in several kinds of crimes as a strategic element in the actions of individuals that took advantage of the inherent incoherence of this space, a consequence of the juxtaposition of sovereignties and distinct legal codes in order to manage loopholes. The effect of the border is verifiable
\end{abstract}


in several scopes of its inhabitants' lives, whether legal or not. Committing crimes, law enforcement and actions by the state gain peculiar connotation in this space. The escape through the border, which places the perpetrator under another jurisdiction, by which he/she cannot be punished, is precisely the great strategic possibility that the border offers. Through the analysis of the crimes of contraband, cattle stealing and slave grooming, as well as maintenance of slave possession and freedom, we will approach the aspects of this boundary space.

Key words: Border. Crime. Law.

\section{Introdução: os crimes e a concepção de fronteira}

A ideia central desse artigo fundamenta-se no entendimento de que existem crimes peculiares a um espaço de fronteira - ou melhor - de que o espaço de fronteira apresenta determinadas características que fazem com que os crimes ali praticados ganhem uma dimensão peculiar. Da mesma forma compreende-se que a ação da burocracia de Estado nesses espaços limítrofes também ganha contornos particulares para lograr exequibilidade.

O ponto de partida da investigação foram os crimes de contrabando - em Processos Crimes referentes a municípios da fronteira sul do Brasil, quais sejam, Alegrete, Uruguaiana, Santana do Livramento e Quaraí, na segunda metade do século XIX. A prática de contrabando configura inquestionavelmente um crime de fronteira, já que se trata de um delito que só pode ocorrer onde há uma fronteira, ou por haver atravessado alguma fronteira em algum momento mesmo que seja apreendido já muito longe do limite político propriamente dito. Contudo, não foi apenas nos crimes de contrabando que a presença e ação da fronteira ficou explícita, mas tomando a totalidade dos Processos Crimes ${ }^{1}$ existentes para o recorte espaço-temporal indicado acima, ficou evidente a importância do espaço de fronteira na ocorrência de um número expressivo de crimes presentes naquelas fontes. $\mathrm{O}$ espaço de fronteira

\footnotetext{
${ }^{1} \mathrm{O}$ total de processos crimes referentes aos municípios de Alegrete, Uruguaiana, Santana do Livramento e Quarai, entre 1845-1889, somam 2.503. Destes, 839 foram selecionados para análise por referirem-se a algum dos tipos de crimes que interessavam à investigação, independente de demonstrarem relação explícita com a fronteira. Aqueles que apresentaram vínculo manifesto com o espaço de fronteira totalizaram 517, o que significa $21 \%$ do total de processos existentes para o recorte espaço-temporal referido. Todos os processos crimes estão disponíveis no Arquivo Público do estado do Rio Grande do Sul (APERS).
} 
figurava nos mais variados tipos de crime não apenas como o local de cometimento dos delitos, mas como um elemento estratégico daquelas ações.

Vale mencionar que a forma como a fronteira aparecia nas fontes chocava com o conceito de fronteira compartilhado em geral pela historiografia, sobretudo do Rio Grande do Sul, até aquele momento. Nesse sentido, cabe informar que o conceito de fronteira é muito caro à produção historiográfica rio-grandense, e platina em geral, em função de que esses territórios se configuraram historicamente como espaços de fronteira, ou seja, o entendimento que se tem da fronteira pode-se dizer que informa a maneira como se interpreta e escreve a história dessas regiões. ${ }^{2}$

A partir da perspectiva historiográfica tradicional, a fronteira era compreendida como uma linha, um limite que exercia função de barreira. As relações que se davam através dessa baliza só eram concebíveis a partir de uma perspectiva estritamente belicista, no sentido de proteger ou expandir o território e, sendo assim, apenas os estados podiam figurar como os elementos que tomavam parte nessa relação, já que os habitantes de um lado e outro seriam sempre opostos e inimigos. Essa concepção, portanto, pautava-se por narrativas lineares que partiam de uma ideia pré-concebida de Estado e Nação, identificada com os limites políticoadministrativos consolidados a posteriori, direcionando a explicação a fim de legitimá-los.

Posteriormente, essa concepção tradicional de fronteira revelou suas limitações sendo contraposta por um entendimento em relação a esse espaço que avançou e refinou largamente a análise. Principalmente no que se refere ao contexto historiográfico rio-grandense, os anos 1990 foram profícuos nesse tipo de debate. Em lugar de render centralidade ao aspecto de limite desempenhado pela fronteira, enalteceu-se a dimensão de contato que ela exerce. Dessa forma, a fronteira passou a ser compreendida como um lugar de integração, e não mais de separação, sendo percebida como um espaço e não como uma linha.

\footnotetext{
${ }^{2}$ Para essa discussão historiográfica ver: "Apologia à fronteira (manejada): uma forma de entender a fronteira." pp.63-104. In: THOMPSON FLORES, Mariana F. da C., Crimes de Fronteira. A criminalidade na fronteira meridional do Brasil (1845-1889), Porto Alegre, EDIPUCRS, 2014. FARINATTI, Luís Augusto E.; THOMPSON FLORES, Mariana F. da C., "A fronteira manejada: apontamentos para uma história social da fronteira meridional do Brasil (século XIX)". In: HEINZ, Flávio (org.). Experiências nacionais, temas transversais: subsídios para uma história comparada da América Latina. São Leopoldo: Oikos, 2009.
} 
A partir dessa historiografia o território que configura atualmente o Rio Grande do Sul passou a ser considerado como componente do "espaço platino", e sua delimitação geopolítica compreendida como um intrincado processo histórico permeado pelos constantes avanços e recuos das demarcações territoriais. Ao compreender, portanto, a fronteira como um ambiente de integração, fez-se possível apreender as relações, e também os conflitos, ocorridos nesse espaço no nível dos sujeitos fronteiriços e dos grupos de interesse dos quais faziam parte e não mais travadas, estritamente, entre os estados.

Essa forma de interpretar o espaço de fronteira se estabeleceu na historiografia de maneira quase inconteste e deixou encobertos alguns problemas metodológicos. Ao postular uma ideia de fronteira como espaço de integração, entendendo que essa integração se dava de forma plena no sentido de que as comunidades fronteiriças acabavam por se identificarem mais entre si do que com seus poderes centrais, essa concepção de fronteira incorreu inadvertidamente em uma falha fundamental: o apagamento da fronteira propriamente dita.

A partir da análise dos processos crimes, percebi que os sujeitos habitantes desse espaço demonstravam saber que viviam em um espaço de fronteira, sabiam, inclusive, em muitos casos, indicar onde passava a linha da fronteira e que esse limite colocava em contato estados com soberanias e leis distintas, as quais geravam brechas e margens decorrentes dessa justaposição que eram manejadas pelos fronteiriços nas suas ações cotidianas. Não se trata de negar a manifesta integração que um espaço de fronteira promove entre as comunidades de ambos os lados, nem querer afirmar que era complicado transitar nesse espaço - pelo contrário. São notórias as diversas relações travadas através da fronteira, contudo, é preciso não incorrer na supressão da dimensão de limite que também é própria a esse espaço. As relações estabelecidas nesse espaço devem ser consideradas como "transfronteiriças" porque atravessam o limite e não porque o desconsideram. ${ }^{3}$

Em um processo em que Roberto Coronel, Dionísio Sancedo e Mariano Marques de Figueiredo eram suspeitos de haverem cometido crime de assassinato, seus depoimentos revelam a naturalidade de viver dos dois lados da fronteira.

\footnotetext{
${ }^{3}$ GRIMSON, Alejandro. La Nación en sus límites: contrabandistas y exilados en la frontera Argentina-Brasil. Barcelona: Editorial Gedisa, 2003. p. 24.
} 
Roberto Coronel, 20 anos de idade, solteiro, sem ofício porque tinha chegado recentemente a Uruguaiana (havia 12 dias), disse que, no dia primeiro de janeiro, veio de Corrientes para a Ilha Grande (ilha localizada no Rio Uruguai) acompanhado de Dionísio Sancedo, a quem chamava de Pancho Sancedo, atrás de um tropeiro com quem estava fazendo tropa de gado bovino. No dia seguinte, passaram para a província rio-grandense, e no dia 3 de janeiro voltou sozinho para Corrientes permanecendo lá por seis dias. Na data do interrogatório fazia três dias que Roberto havia retornado a Uruguaiana. O depoimento de Dionísio Sancedo, 22 anos de idade, solteiro e jornaleiro, diverge em alguns pontos das declarações dadas por seu companheiro no que se refere às datas. Contudo, o trajeto percorrido por ele foi o mesmo relatado por Roberto, a não ser pelo fato de que, antes de chegar à Ilha Grande, Dionísio tinha vindo de Entre Rios, onde havia conduzido tropas de gado.

O que deve chamar a atenção nesses trechos é a declarada facilidade com que demonstravam ir e vir pela fronteira em função de trabalhos sazonais e interesses momentâneos, o que ficou mais evidente ainda quando os acusados responderam igualmente a respeito de se costumavam conduzir seus passaportes durante essas andanças pela fronteira. Roberto Coronel, por exemplo, afirmou que "não trouxe passaporte e que não se apresentou a autoridade alguma e que estava acostumado a passar d'aqui para Corrientes e de lá para este lado sem passaportes". 4

O ato corriqueiro de "cruzar a fronteira", ação cotidiana e inerente à prática de seus habitantes, demonstra a fluidez desse espaço, contudo, também aponta a ideia do "atravessar para o outro lado", onde o indivíduo passa a ser imediatamente forasteiro, estrangeiro. 5 Os espaços de fronteira são, sem dúvida, espaços peculiares. O fato de ser o local de vizinhança com o outro, seja este outro um país, província ou soberania, evoca seu significado mais evidente: cumprir a função de separação e contato ao mesmo tempo. E ainda que se saiba que os indivíduos desse espaço desfrutam de autonomia de ação, não é possível ignorar que os respectivos Estados se

\footnotetext{
${ }^{4}$ Arquivo Público do Estado do Rio Grande do Sul (APERS). Poder Judiciário. Cível e Crime. Processos Crime. Uruguaiana. Caixa 316. $n^{\circ}$ 2636, 1872.

${ }^{5}$ A questão da identidade no contexto fronteiriço está relacionada à noção da "estrangeiridade", cunhada pelo antropólogo Alejandro Grimson, em que o fato de habitar um espaço de fronteira sugere, de forma recíproca e incontornável, o fato de ser estrangeiro diante dos habitantes do outro lado. Mesmo que, como se sabe, os Estados Nacionais ainda não estejam devidamente estabelecidos e, respectivamente, nem as identidades nacionais, estaremos falando de múltiplas relações de identidade possíveis, como as provinciais, por exemplo, que se demarcam de um lado e outro da fronteira. GRIMSON, Alejandro. La Nación en sus límites: contrabandistas y exilados en la frontera Argentina-Brasil. Barcelona: Editorial Gedisa, 2003. p.24.
} 
fazem presentes ali através de uma burocracia específica, como leis, guardas de fronteira, alfândegas. Estado e fronteira não configuram um o oposto do outro, mas a fronteira significa o alcance do seu centro de poder, mesmo considerando-se todas as margens disponíveis à ação das autonomias locais. O limite político em si, a linha por onde passa a fronteira, constitui uma delimitação imposta pelo Estado e, embora seja abstrato, tinha sua localização precisamente reconhecida pelos fronteiriços que sabiam que o mesmo cumpria função concreta nas suas vidas. Dessa forma, os fronteiriços demonstravam nitidamente a noção de que circular pela fronteira não era difícil nem penoso, mas movimentar-se do seu lado, ou do outro lado, acarretava diferentes ações e questões a serem levadas em conta. Assim, era premente aos fronteiriços lidar com essas descontinuidades, para manejá-las. Diversas pessoas desenvolveram partes importantes de suas vidas no outro lado ou, pelo menos, contavam de alguma forma com aquele espaço nas suas estratégias sociais. Por serem cientes de habitarem um espaço de fronteira, valiam-se da incoerência inerente a esse espaço para manejar suas brechas. A ação da fronteira é verificável em todos os âmbitos da vida dos fronteiriços, seja na legalidade ou ilegalidade. Vários trabalhos têm demonstrado, direta ou indiretamente, partindo de diferentes perspectivas, a importância da fronteira como espaço de estratégia para os sujeitos que a habitavam ou estavam ligados a ela de alguma forma ${ }^{6}$.

Refiro-me como "fronteira manejada" a essa proposta de compreensão do espaço de fronteira. Empreender a análise de um espaço de fronteira a partir da sua

\footnotetext{
${ }^{6}$ Dentre estes, considero dois em especial que apontaram a fronteira como espaço de estratégia para os sujeitos, refiro-me aos trabalhos de Luís Augusto Farinatti e Márcia Volkmer. O primeiro, em sua tese de doutorado, abordou a elite agrária da fronteira oeste do Rio Grande do Sul, entre 1825 e 1865, demonstrando que, através da diversificação das atividades econômicas e da combinação de relações sociais e familiares, esta conseguia manter-se e reproduzir-se no seu lugar social. Para tanto, a situação de fronteira era um elemento imprescindível nessa estratégia, sendo manejada pelos atores sociais de acordo com os contextos dados. Na dissertação de Márcia Volkmer, a atuação da fronteira fica evidente na ação de saladeristas uruguaios que atravessaram o limite político territorial e estabeleceram charqueadas na região da fronteira no lado rio-grandense, correspondendo a necessidades conjunturais. FARINATTI, Luís Augusto E. Confins Meridionais: famílias de elite e sociedade agrária na Fronteira Sul do Brasil (1825-1865). Tese de Doutorado - Rio de Janeiro: PPGHIS-UFRJ, 2007. VOLKMER, Márcia S. "Onde começa ou termina o território pátrio": os estrategistas da fronteira: empresários uruguaios, política e a indústria do charque no extremo oeste do Rio Grande do Sul (Quaraí, 18931928). Dissertação de Mestrado - UNISINOS, São Leopoldo, 2007. Para o período colonial ver: OSÓRIO, Helen. O império português no sul da América: estancieiros, lavradores e comerciantes. Porto Alegre: Editora da UFRGS, 2007. GIL, Tiago Luís. Infiéis transgressores: os contrabandistas da fronteira (1760-1810). Dissertação de Mestrado - IFCS/UFRJ, 2002. Para o período imperial ver: GUAZZELLI, Cesar Augusto Barcellos. O horizonte da Província: A República Rio-Grandense e os caudilhos do Rio da Prata (1835-1845). Porto Alegre: Linus, 2013. VARGAS, Jonas M. Entre a paróquia e a Corte: a elite política do Rio Grande do Sul (1850-1889). Santa Maria: Ed. da UFSM, 2010. YOUNGER, Joseph. "Corredores de comércio e salas de justiça: lei, coerção e lealdade nas fronteiras do Rio da Prata”. Revista Aedos, v. 1, n. 1, 2008.
} 
compreensão enquanto "manejada" requer partir do paradoxo original de que a fronteira é, ao mesmo tempo, e sempre, separação e contato. Para tanto, é preciso reduzir as escalas de análise e posicionar os sujeitos considerando que a fronteira não é um dado fixo, mas corresponde a contextos dinâmicos, e, dessa forma, tampouco os fronteiriços constituem-se em uma categoria homogênea.

\section{Os crimes na(da) fronteira: o ambiente propício, os limites e o alcance da ação da justiça}

No que toca ao papel do Estado nesses espaços, desde o cometimento de crimes, passando pelo cumprimento da lei e pela ação da justiça, todos os aspectos ganham configurações peculiares. Havia resistência, por exemplo, por parte dos magistrados em assumir comarcas em lugares muito afastados dos centros de poder, fazendo com que muitas delas jamais conhecessem seu juiz de direito nomeado, os chamados "juízes virtuais", ou que contassem apenas por períodos breves com a presença do magistrado que logo pedia licença de afastamento por motivos de saúde, políticos, etc. Essas comarcas eram chamadas de "virtualmente providas". Essa situação ocorreu na implementação da Comarca de Alegrete em 1850, que abrangia também o município de Uruguaiana. Apesar de ter juiz de direito nomeado, este jamais se apresentou, e, apenas em 1854, esta comarca finalmente foi provida de um juiz presente, o bacharel José Antônio de Oliveira Silva. Muitos magistrados nomeados para cargos no poder judiciário em municípios de fronteira não assumiam efetivamente suas funções por temerem invasões estrangeiras e por não conseguirem exercer controle sobre os criminosos que fugiam para os países vizinhos. 7

Da mesma forma, os altos índices de criminalidade das regiões de fronteira eram temas recorrentes em Relatórios de Presidentes da Província. Nesses casos, por conveniência, frequentemente os discursos oficiais relacionavam a incidência da criminalidade na fronteira com a grande presença de estrangeiros. Em 1856, o presidente da província Jeronymo Francisco Coelho referia-se ao aumento da criminalidade no Rio Grande do Sul e apontava suas causas para a fronteira:

\footnotetext{
${ }^{7}$ SODRÉ, Elaine L. de Vargas. A disputa pelo monopólio de uma força (i)legítima: Estado e Administração Judiciária no Brasil Imperial (Rio Grande do Sul, 1833-1871). Tese de Doutorado - PPGH-PUCRS, Porto Alegre, 2009. p. 287
} 
“(...) a facilidade com que esses criminosos se passam por qualquer ponto de nossa vasta fronteira para os Estados vizinhos, com um dos quais somente temos tratado para a extradição, porém está sujeita a tão morosas formalidades, que completamente inutilizam os fins do tratado; (...) criminosos dos Estados vizinhos vem clandestinamente para o nosso território aumentando o numero dos primeiros (...).”8

$\mathrm{Na}$ realidade, as altas taxas de criminalidade nas fronteiras não eram "mérito" apenas dos estrangeiros. Assim como criminosos dos países vizinhos procuravam esconderijo no Brasil, o inverso também era verdadeiro. Da mesma forma, assim como inúmeros réus eram oriundos de províncias argentinas ou orientais, outros tantos réus eram brasileiros, muitos nascidos na província rio-grandense. A possibilidade de fuga que esse espaço oferece, portanto, é um elemento diferencial. É certo que em qualquer espaço alguém que comete um crime sempre pode fugir, contudo, em uma fronteira, essa fuga assume outra conotação na medida em que nesse contexto se está lidando com diferentes soberanias, sendo que em muitos casos ainda não há tratados sobre como lidar com essas questões, ou como referiu o presidente da província Jeronymo Coelho as "morosas formalidades" "inutilizam os fins do tratado".9

A definição legal que declarava que um réu só podia ser julgado por um determinado crime no lugar em que foi cometido ou no lugar de sua residência ou nascimento ${ }^{10}$, da qual decorria a impossibilidade de se processar um crime praticado baixo a jurisdição de outro país, abria a possibilidade de atravessar a fronteira para cometer um crime e regressar livre de qualquer penalização legal, dada a impossibilidade de julgar um delito cometido sob a alçada de outra soberania e autoridade judicial. Sendo assim, se a fuga é justamente a grande possibilidade de estratégia que a fronteira oferece, pode-se conjeturar que a maior parte dos sujeitos

\footnotetext{
${ }^{8}$ Arquivo Histórico do Rio Grande do Sul (AHRGS). Relatório do Presidente da Província do Rio Grande do Sul. A-7.03. 1856.

${ }^{9}$ O Brasil assinou tratados com o Estado Oriental e com a Confederação Argentina, na década de 1850, que pretendiam dar conta do problema das violações fronteiriças, o que demonstra claramente a preocupação com a gravidade desta situação. Em 12 de outubro de 1851, foi acordada com o Estado Oriental a entrega recíproca de criminosos, desertores e escravos. Em 1856, foi acertada com a Confederação Argentina a devolução de desertores. Ver: Tratado de 12 de outubro de 1851. Tratado de Comercio e Navegación. IN: Tratados y Convenios Internacionales - suscritos por Uruguay en el periodo mayo de 1830 a deciembre de 1870. República Oriental del Uruguai. Secretaria del Senado - Documentación y Antecedentes Legislativos: Montevideo, 1993. Tomo 1. OLIVEIRA, José Cardoso de. Actos Diplomáticos do Brasil. Brasília: Editora do Senado Federal, 1997. Tomo I.

${ }^{10}$ Código de Processo Criminal de 1832. Art. 257.
} 
que atravessavam a fronteira para cometer delitos tenham conseguido retornar sem serem pegos e, consequentemente, sem gerar um processo.

A estratégia da fuga e esconderijo através da fronteira era reforçada portanto pela ausência de tratados internacionais que estabelecessem as extradições de criminosos e desertores. Por outro lado, as redes que se constituíam e ligavam os dois lados da fronteira também chegavam ao poder institucional e encontram-se, em alguns processos, casos em que a amizade e cooperação entre membros de instituições de polícia e guarda dos dois lados possibilitaram a captura de fugitivos que varavam o limite, independentemente da existência ou ausência de tratados que formalizassem essa situação.

O réu Simão Mendes d'Oliveira, que feriu gravemente Manoel Souza Nunes em uma briga numa carreira ("numa reunião de povo"), fugiu para o Estado Oriental após ter cometido o crime. O delegado de polícia de Alegrete, Libindo Nunes Coelho, afirmou que o réu era reconhecido por todos como "assassino e turbulento", e o subdelegado, José Maria de Souza, sugeriu que a única solução para o réu era ser recrutado para a Marinha de Guerra "onde ainda poderá ser útil”. Frente à fuga do criminoso, sua captura foi requisitada pelo delegado ao Comandante de Fronteira do lado oriental, Diogo Lamas. ${ }^{11}$

Esse mesmo Comandante de Fronteira já havia precisado de serviço semelhante por parte das autoridades do lado rio-grandense. Em 1848, um grupo de soldados e o tenente do $7^{\circ}$ Corpo de Cavalaria da Guarda Nacional foram acusados de terem assassinado o oriental imigrado Miguel Lemos. A denúncia e o pedido por punição dos réus foram feitos pelo próprio Diogo Lamas a Manoel Barreto Pereira Pinto, Major Comandante da ala esquerda da linha, tendo sido atendido. ${ }^{12}$

Dessa forma, a mesma autonomia local, proporcionada pela distância do centro de poder, que facilitava a ação de criminosos que se mantinham impunes, também atuava na constituição de redes, não formais, entre os detentores de poderes institucionais para a solução extraoficial de transgressões, e uma questão limitante da ação do Estado podia tornar-se potencialmente uma capacidade de ação do mesmo.

\footnotetext{
${ }^{11}$ APERS. Poder Judiciário. Cível e Crime. Processos Crime. Alegrete. Caixa 46/Maço 80. No 2797. Ano 1854.

${ }^{12}$ APERS. Poder Judiciário. Cível e Crime. Processos Crime. Alegrete. Caixa 42/Maço 77. No 2680. Ano 1848.
} 
Contudo, os limites e alcances do Estado no espaço fronteiriço não se esgotavam nessas questões de manejo das autonomias locais. A seguir, através da análise de alguns crimes, pretende-se aclarar as estratégias exitosas cumpridas por criminosos e os entraves colocados pela ação da justiça.

A evasão de criminosos pela fronteira, portanto, contemplava sujeitos que levavam suas vidas nesse espaço cometendo crimes e fugindo - contrabandistas, ladrões, bandos de ladrões, assassinos. Paralelo a esses infratores que varavam o limite político a fim de colocarem-se fora do alcance da jurisdição com poder de incriminá-los, constam fronteiriços em geral que podiam circunstancialmente desfrutar das possibilidades que a fronteira oferecia para evadir-se de alguma responsabilidade ou perceber determinados ganhos. Havia pessoas que eventualmente envolviam-se com crimes, bem como, um sem número de desertores e de devedores, que empreendiam fugas disfarçadas de mudança, a fim de livrar-se do compromisso do pagamento, transferindo-se com toda sua família para o outro lado da fronteira. Entre aqueles fronteiriços que se valiam regularmente do espaço limítrofe para realizar ou incrementar negócios, mas não necessariamente precisavam atravessá-lo para valer-se de suas prerrogativas, estavam os grandes comerciantes cujo enriquecimento se fez pela prática concomitante da importação de mercadorias por contrabando e por comércio regular. Além destes, outro personagem infrator revelado pelo contexto especifico da fronteira são os sedutores de escravos, que viviam justamente de aliciar e atravessar escravos para a fuga pela fronteira.

Dentre os ladrões da fronteira destacam-se na documentação aqueles que se dedicavam ao roubo de gado. $\mathrm{O}$ abigeato era um crime comum a toda a província riograndense dado o perfil econômico voltado à produção pecuária. Contudo, no espaço da fronteira esse crime adquiria características peculiares e mais de um modo de ocorrer assumindo significados variados, considerando os diferentes posicionamentos dos atores sociais que o empreendiam. Era comum, por exemplo, o roubo de pequenas porções de gado ou cavalos para tentar vendê-los do outro lado da fronteira, tentando assim despistar desconfianças a respeito da procedência daqueles animais. No entanto, dificilmente os demais estancieiros não reconheciam as marcas que os animais levavam para identificar seu proprietário, além disso, havia uma série de posturas que indicavam que não se comprasse animais cujo vendedor não atestasse através das guias de compra e venda sua origem lícita. Porém, atraídos 
pelos baixos preços, muitas vezes criadores e proprietários de açougues compraram reses roubadas fazendo vistas grossas para tal situação.

A fim de diminuir as suspeitas, muito do gado roubado era carneado para que a carne já fosse consumida e seus subprodutos vendidos separadamente, como sebo, couro, chifres e cascos. Ainda assim, frequentemente o ladrão era descoberto através do couro do gado - que levava a marca do proprietário - seja por usá-lo para algum fim (móveis, revestimentos, arreios, etc.) ou por tê-lo vendido a algum negociante que informou quem lhe havia repassado o couro. Não se cogitava desfazer-se do couro, já que era um produto de grande valor de mercado. Ou seja, desfazer-se inteiramente do couro significava perder parte da rentabilidade daquele roubo. Os couros eram uma importante moeda de troca nas relações comerciais dessa sociedade eminentemente pecuária. Esses couros, chamados "couros de consumo", eram retirados do gado abatido para o abastecimento da estância ou de animais que morriam, mas também podiam ser provenientes de roubo. Sua venda podia ser direta dos produtores, ou do autor do roubo, para os comerciantes em troca de gêneros para consumo ${ }^{13}$

Outra estratégia recorrente era a de valer-se de propriedades de terra de que se dispunha dos dois lados da fronteira, ou seja, era possível roubar as reses e levá-las para sua propriedade rural localizada do outro lado. ${ }^{14}$ Nesse sentido João José Brazeiro foi acusado de ter passado 3 mil reses da estância de Alexandre d'Abreu Valle Machado, localizada no Estado Oriental, para a sua propriedade no Rio Grande do Sul, em 1853.15 Os casos relatados denotam características recorrentes dos roubos de gado nesse espaço: os roubos de gado imediatamente carneados e a frequência dos

\footnotetext{
${ }^{13}$ FARINATTI, Luís Augusto E. Confins Meridionais... Ob. Cit. p.96. Em Alegrete, no ano de 1852, Dona Rita Gomes de Oliveira denunciou José Caetano da Rosa, seu vizinho de propriedade, porque este costumava roubar seu gado os quais "carneava em grandes quantidades com a finalidade de lucrar grande porção de couros, sêbo, graixa e sabão que effectivamente vendia". APERS. Poder Judiciário. Cível e Crime. Processos Crime. Alegrete - Maço 78, nº 2731. Ano 1852.

${ }^{14}$ Ao longo do século XIX, houve a presença maciça de brasileiros, sobretudo rio-grandenses, proprietários de terras com gado no Uruguai, os quais, invariavelmente, também possuíam propriedades no Rio Grande do Sul. Segundo Susana Bleil de Souza e Fabrício Prado, no ano de 1857 "estimava-se que os rio-grandenses possuíssem cerca de 30\% do [norte do] território oriental". O norte do Uruguai era como uma "extensão dos campos de pastoreio do Rio Grande" e essa invernada de engorda do gado era fundamental para o abastecimento das charqueadas. Ver: SOUZA, Suzana Bleil de \& PRADO, Fabrício Pereira. "Brasileiros na fronteira uruguaia: economia e política no século XIX”. In: GRIJÓ, GUAZZELLI, KÜHN \& NEUMANN (org.). Capítulos de História do Rio Grande do Sul: Texto e Pesquisa. Ed. Da Universidade/ UFRGS, 2004. p.133 e 134. (Grifo meu).

${ }^{15}$ APERS. Poder Judiciário. Cível e Crime. Ordinárias. Uruguaiana - Maço 22, nº 550. Ano 1853.
} 
roubos entre vizinhos ou proprietários, quer dizer, entre indivíduos que não poderiam ser identificados como pobres, despossuídos. Ocorriam, com mais frequência, é verdade, os casos de roubos unitários, de uma cabeça de gado, em geral relacionados ao consumo imediato da carne, muitas vezes, por questão de subsistência. Sua alta incidência também vai ao encontro do elevado número de jornaleiros, ou homens sem ocupação definida, que se destacaram entre o perfil de autores frequentes dos furtos de gado caracterizado por homens preferencialmente jovens, solteiros ou casados, quase na mesma proporção, sem ocupação definida ou com trabalho vinculado às tarefas agropastoris (pessoas que tinham fácil acesso ao gado devido às ocupações que desempenhavam). ${ }^{16}$

O caso do acusado João José Brazeiro lembra outra questão relativa ao manejo de gado através da fronteira, fosse lícito ou não: o fato de que circular do seu lado, ou do outro lado, acarretava diferentes ações e questões a serem levadas em conta. O trabalho de Joseph Younger ${ }^{17}$ é emblemático da utilização do espaço de fronteira nas estratégias econômicas. $\mathrm{O}$ autor demonstra que as redes comerciais transfronteiriças transbordavam os recursos legais existentes em uma e outra soberania, respectivamente de um lado e outro da linha de fronteira. Dessa forma, fazer valer direitos de propriedade nesse contexto significava combinar uma série de recursos jurídico-institucionais de ambos os lados, sem que, contudo, eles garantissem posse de fato. Os atores fronteiriços lançavam mão de diferentes instrumentos, como processos judiciais, acertos com autoridades locais, sistema notarial público, de forma quase experimental buscando assegurar a posse de bens que atravessavam a fronteira em um espaço juridicamente heterogêneo.

Uma imagem mais recorrente no senso comum no que se refere à criminalidade na fronteira remete à ação de bandos armados de criminosos profissionais. ${ }^{18}$ As referências encontradas sobre a ação de bandos de salteadores nos

\footnotetext{
${ }^{16}$ Esse panorama aponta para padrões semelhantes aos encontrados por Maria Aparecida Lopes no contexto da fronteira entre México e Estados Unidos, no último quartel do século XIX. Lopes demonstra que, diferentemente do que o discurso oficial propalava, os responsáveis pelos roubos de gado tinham moradia fixa, vínculos familiares e tinham ofícios, mesmo que fosse trabalho por jornal, sendo que quase $50 \%$ das infrações cometidas por pessoas com ofícios ligados à pecuária eram de abigeato. LOPES, Maria Aparecida de S. De costumbres y leyes: abigeato y derechos de propiedad en Chihuahua durante el Porfiriato. México, D.F: El Colegio del México; Centro de Estudios Históricos, 2005. p.175 e 548.

${ }^{17}$ YOUNGER, Joseph. "Corredores de comércio...". Op. Cit.

${ }^{18}$ A autora Maria Aparecida Lopes identificou para a região de Chihuahua, em meados do século XIX, que as referências frequentes ao crime de abigeato indicam um tipo de organização delitiva de caráter coletivo,
} 
processos crimes concentram-se no período final do século XIX, constituindo casos emblemáticos nos quais denota-se a centralidade da fronteira, ou da fuga através dela, nas estratégias de ação e imunidade. Segundo o Relatório do Presidente da Província João Pedro Carvalho de Moraes, de 1875, em fins de junho de 1874 apareceu no município de Dom Pedrito, que também fazia fronteira com o Estado Oriental, um grupo de salteadores que, tendo cometido diversas barbaridades, entre assassinatos e roubos, evadiram-se da perseguição da polícia indo para o Estado Oriental. Meses depois, em outubro, o mesmo bando reapareceu em Alegrete, onde perpetraram crimes semelhantes aos anteriores. O grupo, que se estimava ser composto por cerca de dezesseis homens, novamente conseguiu escapar do cerco policial fugindo de volta para o Estado Oriental. ${ }^{19}$

Em Uruguaiana, no ano de 1879, uma quadrilha, composta por nove homens, dos quais apenas se conseguiu prender dois, é descrita pelo Promotor Público, Joaquim dos Santos Coelho, da seguinte maneira,

\begin{abstract}
“(...) não tem emprego nem ocupação, andão sempre occultos e misteriosos, e não tem permanência fixa, discriminada e clara; vão se acobertando com a noticia de aggregados deste ou daquelle. Esta horda de indivíduos tem se tornado a muito tempo o flagello do $2^{\mathrm{O}}$ Districto, onde, combinados com outras hordas de Corrientes, praticão toda a sorte de depredações, furtando animais de toda a espécie, fasendo carneações nocturnas, assolando todas as fazendas [...]. O producto de seus latrocínios e depredações é muitas veses levado para Corrientes onde estão os outros sócios [...].”2o
\end{abstract}

A ação desse bando em espacial chama a atenção porque além de valerem-se do recurso de fuga pela fronteira também contavam com agentes (membros) localizados na província de Corrientes para onde direcionavam o fruto de seus roubos.

Em 1880, em Alegrete, soldados da polícia sob o comando do Delegado receberam ordens para prender o entrerriano Estanislau de tal e Fermino Soares por

conformando a ação de grandes bandos com vínculos com pastores, informantes e compradores, muitas vezes, localizados do outro lado da fronteira. LOPES, Maria Aparecida de S. De costumbres y leyes... Op. Cit. p.185186 e 526.

19 Relatório do Presidente da Província João Pedro Carvalho de Moraes. 1875. Disponível em: http://www.seplag.rs.gov.br/upload/1875 Joao_Pedro_Carvalho_de_Moraes_Falla.pdf Acesso em: setembro de 2011.

${ }^{20}$ APERS. Poder Judiciário. Cível e Crime. Processos Crime. Uruguaiana. Caixa 377. Maço 83. n 2915, 1883 (1879). 
já estarem nos seus encalços há muito tempo em função de crimes e desordens cometidos por eles. Segundo a denúncia do Promotor Público, Fermino e Estanislau "eram chefes de uma quadrilha de larápios, terror dos criadores e possuidores de cavallos nesse município". Quando o bando se reunia, eram frequentes as queixas porque, onde se estabeleciam "ao som de guitarra e ao tinir de copos, transformavam ora sua casa, ora os ranchos próximos e lugar scenario de devassidão, jogo, lutas, donde não raras vezes resultavam graves conflictos e sérios ferimentos entre os convivas". No ato da prisão, os criminosos tentaram fugir em direção à fronteira "para não soffrerem a acção da justiça", mas houve conflito que decorreu na morte de vários soldados, bem como de Fermino Soares. ${ }^{21}$

Pelos processos crimes também se identificou a prisão de outro grande bando em Uruguaiana, no ano de 1883. Uma quadrilha que assaltava casas de comércio, denominada de "companhia de ladrões", foi localizada pelas autoridades policiais, que conseguiram prender oito dos dez membros do bando. ${ }^{22}$ No ano seguinte, a quadrilha de nove homens liderada pelos orientais Hermenegildo Sandaño e Theodoro Azuaga veio da Província de Corrientes para Uruguaiana com o fim de assaltar a casa de Dona Claudiana Rodrigues da Silva. Enquanto isso, na margem do Rio Uruguai, Gregório Barranqueira esperava pelo bando guardando a canoa na qual retornariam. Gregório foi o único preso, sendo que os demais conseguiram fugir para Corrientes.

Conforme se percebe, a proliferação desses bandos, no final do século XIX, identificada inclusive pelo poder público, significava um meio de sobrevivência para determinados sujeitos que, sob efeito do fechamento da fronteira agrária e agravamento da concentração fundiária ao longo do século XIX ${ }^{23}$, percebiam poucas oportunidades de sobrevivência frente à proletarização do serviço rural e a restrita oferta desses postos de trabalho. Dessa forma, vão se lançar à prática de crimes atravessando constantemente a fronteira para realizar roubos, regressar e vender ou usufruir dos produtos do delito e manter-se em movimento a fim de estender ao

\footnotetext{
${ }^{21}$ APERS. Poder Judiciário. Cível e Crime. Processos Crime. Alegrete. Caixa 66. Maço 93 e 94. n 3255, 1880.

${ }^{22}$ APERS. Poder Judiciário. Cível e Crime. Processos Crime. Uruguaiana. Caixa 376. Maço 82 e 83. no 2900, 1883.

${ }^{23}$ A respeito da concentração fundiária na região da campanha sul-rio-grandense ao longo do século XIX ver GARCIA, Graciela Bonassa. O domínio da terra: conflitos e estrutura agrária na campanha rio-grandense oitocentista. Dissertação de Mestrado - UFRGS, Porto Alegre, 2005.
} 
máximo sua ação criminosa. Essa imagem aproxima-se da que foi demonstrada por Maria Aparecida Lopes, para a fronteira norte do México, no quartel final do século XIX, da ação de bandidos profissionais que agiam em grupos organizados, contando com uma complexa rede de informantes e receptadores que envolviam indivíduos de diferentes estratos sociais.

Nesse sentido, é preciso ter o cuidado para não incorrer em uma sobrerrepresentação das camadas pobres, como se, em um determinado momento, apenas elas praticassem crimes, lembrando que inúmeros roubos eram feitos entre (grandes) proprietários que se valiam dos campos contíguos, sem divisões, onde o gado comumente se misturava. Dessa forma, a categoria também usada pela autora Maria Aparecida Lopes, dos roubos de gado por "motivos sociais", dificilmente se verifica, embora tenham sido encontrados casos, concentrados entre 1877 e 1889, de ladrões de gado que em seus processos alegaram fome e pobreza como motivo para terem cometido os furtos. Parece adequado, no entanto, considerar que independente do aparato organizacional de que dispõe o ladrão ou o bando, mesmo as ações de roubo individuais, mais frequentes, podem ser enquadradas como profissionais de alguma forma, como aqueles considerados na documentação como "useiros e vezeiros", que, embora pudessem manter eventualmente relações formais de trabalho, ou outra forma lícita de subsistência, praticamente sustentavam-se desses furtos cometidos constantemente. Em geral realizavam roubos de pequenas porções de gado, mas que representavam somas impressionantes no somatório geral, e podiam ser praticados pelos mais variados estratos sociais.

Outro tipo de crime que carrega as peculiaridades do espaço de fronteira é o contrabando. Nesse caso é importante destacar que o contrabando não constituía uma prática homogênea e, sendo assim, também não se trata de um crime restrito a populares. Na realidade, os contrabandistas que de fato movimentavam o comércio da região tratavam-se de grandes comerciantes que, não raro ocupavam cargos públicos de destaque local. Concomitantemente havia os pequenos contrabandos que não dispunham de um aparato muito elaborado para sua execução e tinham finalidades diversas como revenda, consumo ou encomendas feitas entre conhecidos. Já os grandes carregamentos de contrabando buscavam abastecer as casas de comércio com produtos importados, por um custo bastante inferior ao que se tivessem passado regularmente pela Alfândega. Eles não eram simplesmente 
contrabandistas ou comerciantes, eram, justamente, "comerciantescontrabandistas". 24

Os irmãos Juan e José Comas, constituíam um desses casos de grandes comerciantes regulares, estabelecidos com casa de comércio em Uruguaiana, que dispunham de um aparato organizacional composto por homens armados para escolta, atravessadores, barqueiros, contatos privilegiados na guarda e na Alfândega para a realização de grandes contrabandos. O contrabando nessa sociedade desfrutava de certa invisibilidade que permitia um consentimento social, possivelmente por ser uma prática disseminada, mas também porque as mercadorias de contrabando não eram produtos proibidos de serem comercializados, apenas burlavam o pagamento dos impostos de importação ou exportação, resultando em que, quando se faz referência às mercadorias do contrabando, se está falando das mesmas do comércio lícito. Dessa maneira, o comércio lícito e o ilícito eram duas faces de uma mesma atividade empreendida pelos mesmos sujeitos: a importação e exportação de mercadorias para atender as demandas da região. ${ }^{25}$ Os produtos contrabandeados seguiam a lógica dos diferentes níveis de preço da fronteira. $\mathrm{O}$ sentido das mercadorias - quais as que vinham e quais as que iam - indicava essa diferença. Basicamente, o que saía pela fronteira oeste rumo aos países limítrofes eram carregamentos de erva-mate, farinha, fumo, aguardente, açúcar e algum couro. Em contrapartida, vinha toda a sorte de produtos importados da indústria europeia, que entravam pelos portos de Buenos Aires e Montevidéu e faziam seu caminho até esta fronteira.

Entre as mercadorias que entravam, a maior incidência de importação era, sem dúvida, de fazendas de todos os tipos: das mais baratas e comuns às mais

\footnotetext{
${ }^{24}$ Zacarias Moutoukias, referindo-se ao contrabando colonial no Rio da Prata no século XVII, alerta para a questão da "romantização" do contrabando. Mesmo se tratando de outro contexto diferente deste, seu alerta é bastante pertinente. Nas suas palavras, "[c]uando se aborda el tema del contrabando en la historia comercial de la Hispanoamérica colonial, es casi un acto reflejo imaginar a sus protagonistas organizados en bandas antes que en compañías o sociedades comerciales." MOUTOUKIAS, Zacarias. Contrabando y control colonial en el siglo XVII: Buenos Aires, el Atlántico y el espacio peruano. Buenos Aires: Centro Editor de la América Latina, 1987. p. 98 .

${ }^{25}$ Desde o Código Criminal de 1830, não há diferenciação entre contrabando e descaminho (sendo o contrabando a importação ou exportação de mercadorias proibidas e o descaminho a importação ou exportação de mercadorias permitidas que não pagaram as devidas taxas alfandegárias), existindo apenas a categoria criminal de contrabando, que está reputado pelo artigo 177, no Título IV: "Dos crimes contra o tesouro publico e propriedade publica", Capítulo III da seguinte forma: "Importar ou exportar gêneros ou mercadorias prohibidas, ou não pagar os direitos dos que são permittidos, na sua importação ou exportação." Código Criminal do Império do Brazil de 1830. Rio de Janeiro: Livraria Popular. 1877.
} 
refinadas e dispendiosas. Os demais artigos, tais como utensílios domésticos (panelas, louças), bebidas, baralhos, chapéus, sapatos, cortes de roupas e objetos para senhoras como meias de seda e pregadores de cabelo, também iam de produtos acessíveis, ou comuns, aos mais refinados. A esses se somavam produtos de fabricação ou beneficiamento local, a maior parte derivados de produção primária, que se serviam das mesmas rotas pluviais. ${ }^{26}$

De maneira muito simples podemos dizer que o caminho percorrido pelas mercadorias importadas, que movimentavam o comércio na fronteira oeste do extremo sul do Império do Brasil, era entrar pelo Rio da Prata, pelos portos de Montevidéu ou Buenos Aires, e seguir por uma rota fluvial evidente rio acima até encontrar o Rio Uruguai e descarregar nos portos fluviais de Uruguaiana, Itaqui ou São Borja, ou ser descarregada um pouco antes e seguir por terra, em carretas, sendo introduzida pelas fronteiras secas com o Estado Oriental. Ao longo desse percurso, agregavam-se as produções locais nos entrepostos fluviais articulados a esse trajeto mercantil.

Voltando aos mencionados "irmãos Comas", o conteúdo de um processo crime resultante de uma apreensão de contrabando que sofreram é exemplar de como funcionava sua empresa comercial. Os referidos comerciantes esperavam a introdução de um grande contrabando de cerca de 60 fardos de fazendas importadas na madrugada de 27 de novembro de 1864. Tudo fora acertado com Domingos Quincoza, ex-guarda da Alfândega que havia sido contratado para capitanear o grupo de cerca de 20 homens a cavalo que buscaria, nas margens do Rio Uruguai, em um bote também contratado que aguardava o momento apropriado para atravessar as mercadorias de Restauração e entregá-las ao referido grupo em um lugar previamente combinado na margem brasileira. Domingos Quincoza ainda mantinha bons contatos na repartição e por isso soube que a madrugada de 27 de novembro seria a ideal, sobretudo porque era sábado e nos finais de semana o efetivo da guarda ficava reduzido. Além do mais, sabia-se que uma tormenta se aproximava e por essa razão aquela noite seria muito escura, o que tornaria mais difícil que o bando fosse visto.

\footnotetext{
${ }^{26}$ MEDRANO, Lília Inês Zanotti de. A livre navegação dos Rios Paraná e Uruguay: uma análise do comércio entre o Império Brasileiro e a Argentina (1852-1889). Tese de Doutorado - USP, São Paulo, 1989. p. 3.
} 
O mesmo Domingos ficou responsável pela contratação dos homens que trariam os fardos presos aos seus cavalos, sendo entre um a três fardos por pessoa. Muitos dos homens que participaram da empreitada envolveram-se apenas circunstancialmente no contrabando, ou seja, não eram atravessadores de contrabando por profissão. Eram homens livres, pobres e sem ocupação definida que sobreviviam desses pequenos trabalhos. Um caso desses foi o de Symão Portilho, 26 anos, casado, peão de carretilhas, natural de Corrientes. Confessou ter participado da introdução do contrabando carregando três fardos em seu cavalo (dois grandes na garupa e um pequeno na mão). Fora convidado por Domingos Quincoza e Manoel "Farrapo" e receberia o pagamento de um patacão por fardo que carregasse. Afirmou que eram entre dezesseis e dezoito condutores e que era a primeira vez que participava de um contrabando. O convite para participar do grupo lhe foi feito na mesma noite da ação e, assim que aceitou, já saiu na companhia de Domingos e Manoel e juntaram-se a mais pessoas na sanga do Salso. Juntos foram pela costa do Uruguai até ponta da Ilha Grande onde chegou o bote que trazia os volumes. O grupo conduziu o carregamento escoltado por homens armados prontos para a resistência. Por volta da meia noite, suspenderam a marcha no local denominado "coxilha dos loucos", e Modesto Oliveira de la Palma, Agostinho Silva Filho e Leopoldo Silva avançaram servindo de sentinelas avançados para observar as rondas, patrulhas e transmitir avisos. Ao completarem o percurso, entregaram os fardos de mercadorias pelo muro dos fundos do pátio da casa de negocio de Comas onde havia cerca de seis pessoas do lado de dentro recebendo os fardos. Foi nesse momento que foram surpreendidos pelos guardas da Alfândega com quem entraram em conflito. Alguns dos homens do bando conseguiram fugir e outros foram presos. No entanto, as mercadorias não foram apreendidas no ato porque os guardas careciam de mandado para dar busca na casa dos irmãos Comas. ${ }^{27}$

Em relação aos pequenos contrabandos, ou seja, aqueles empreendidos individualmente, muitas vezes sem nada além de um cavalo para carregar a mercadoria e a escuridão da noite como proteção, o caso de Bibiano Baptista Tubino é notável. Este foi um entre muitos contrabandistas que conduziam sozinhos seu negócio. Eles mesmos cruzavam a fronteira, compravam as mercadorias, faziam o

${ }^{27}$ APERS. Poder Judiciário. Cível e Crime. Processos Crime. Uruguaiana. Caixa 310, nº 2535 e 2536. 1864 e 1865. 
atravessamento clandestino delas e depois se preocupavam em vendê-las. Se fossem pegos pela guarda o prejuízo era todo seu; se tivessem êxito no contrabando, no entanto, não precisariam dividir os lucros com ninguém.

Através de notas publicadas no jornal O Baptistense, a pedido de proprietários de fábricas de sabão existentes em Quarai, veio à tona a denúncia de que Bibiano andava vendendo sabão de porta em porta dizendo que era proveniente de cidades da província como Pelotas, Bagé ou Livramento. Contudo, o preço baratíssimo que oferecia não condizia com a origem lícita da mercadoria, uma vez que o preço corrente do sabão era de 5.700 réis a arroba e Bibiano a vendia por 3 mil réis. Além disso, uma pessoa que comprou o dito sabão como se fosse de Santana do Livramento, embora lá nem existisse esse tipo de fábrica, verificando as barras constatou que eram da Fábrica de San Eugenio no Estado Oriental. Segundo o processo, estimava-se que até ter sido capturado, Bibiano teria passado e revendido sozinho cerca de mil quilos de sabão do Estado Oriental. ${ }^{28}$

Ainda em relação ao contrabando e ao papel desempenhado pela Alfandega, ficam em evidência nesse aspecto a ação e os limites do estado. A instalação da Alfândega em Uruguaiana, em 1849, se deu em função de que o destacado desenvolvimento comercial daquela vila demandava a instalação de um órgão permanente de fiscalização a fim de coibir o contrabando e arrecadar sobre as promissoras transações comerciais. ${ }^{29}$ Após o decreto da Livre Navegação dos rios da Bacia do Prata, em 1852, que assegurava livres de taxação as mercadorias introduzidas por Buenos Aires com destino aos países vizinhos, o comércio que já era vantajoso tornou-se ainda mais lucrativo, e o aumento do volume de transações foi vertiginoso. $3^{0}$

\footnotetext{
${ }^{28}$ APERS. Poder Judiciário. Cível e Crime. Processos Crime. Quaraí. Maço 28. №73. Ano 1889.

${ }^{29}$ A intensa atividade mercantil da região foi apontada por viajantes como Nicolau Dreys, quando por ali passou, entre 1817 e 1838, e Ave-Lallemant, em 1858. DREYS, Nicolau. Notícia descriptiva da Província do Rio Grande de São Pedro do Sul. Porto Alegre: Instituto Estadual do Livro, 1961. p. 126. AVÉ-LALLEMANT, Robert Christian Bertold. Viagem pelo sul do Brasil no ano de 1858. Belo Horizonte: Editora Itatiaia, 1980. p. 236.

${ }^{30}$ Algo que denota o incremento do comércio após a Regulamentação de 1852 foi que a livre navegação estimulou iniciativas privadas e incentivos governamentais para o desenvolvimento de transporte de carga e de passageiros. Foi a partir desse momento que enormes Companhias Fluviais começaram a aparecer na Argentina. Ver: MEDRANO, Lilia Inês Zanotti de. A livre navegação dos Rios Paraná e Uruguay..., Op. Cit., p. 221. Da mesma forma, em 1857, vemos a proposta para a instalação do Vapor Uruguai no Rio Uruguai justificada como muito mais eficiente para o comércio e trânsito de pessoas que as embarcações a vela; ela seria realizada por
} 
Muito antes disso, no entanto, os jesuítas no século XVIII já utilizaram a rota Rio Uruguai - Rio da Prata para enviar suas produções de erva-mate, mel e couros para Buenos Aires. ${ }^{31}$ Nesse sentido, antes da Regulamentação de 1852, o comércio de produtos brasileiros para a Argentina e o Estado Oriental devia ser feito entrando oficialmente pelos portos de Buenos Aires e Montevidéu - sendo que o primeiro detinha o monopólio da navegação e do envio das mercadorias aos mercados compradores - ou por contrabando. Contudo, devido ao conflito existente entre as províncias argentinas e Buenos Aires por autonomia, antes de 1852 já havia uma série de exceções, sobretudo por parte de Corrientes e Entre Rios, que permitiam o comércio direto com o Rio Grande do Sul. ${ }^{2}$

Essa vida comercial intensa, fosse ela lícita ou ilícita, tornava indispensável a existência de uma Alfândega nesse local, sobretudo, porque as Alfândegas eram as maiores estações fiscais em termos de arrecadação, e o Império não podia desdenhar dessa possibilidade de incrementar sua receita. 33 Dessa maneira, a Alfândega existia nesse confim de território e os inspetores que a chefiaram eram homens de fora, nomeados pelo poder provincial ou imperial que precisavam atuar entre a boa convivência com os comerciantes locais e a justificação de sua existência legítima e pertinente naquelas paragens perante o poder central. Uma alfândega que não arrecadasse não tinha razão de existir, de ser mantida em funcionamento. Por outro lado, uma alfândega de funcionamento totalmente rígido e íntegro tampouco garantiria um bom convívio local. Dessa forma, a Alfandega de Uruguaiana estabeleceu um modus operandi que acomodava diversos interesses: o contrabando devia passar por dentro da própria alfandega pagando um valor de imposto que, embora ficasse muito aquém do valor referente ao carregamento real, garantia alguma arrecadação validando a função da repartição fiscal naquele lugar. O corolário dessa conjuntura era o fato de que se o comercio lícito crescia o contrabando também crescia. Um inspetor que coibisse as irregularidades na Alfândega dificultando os

Antonio Rodrigues Chaves Filho, que contava com 10 contos de réis de subvenção do governo para tal empresa. AHRGS. Fazenda. Uruguaiana. Maço 490. s/nº 1857.

${ }^{31}$ MEDRANO, Lilia Inês Zanotti de. A livre navegação dos Rios Paraná e Uruguay..., Op. Cit., p. 147.

${ }^{32}$ Ibidem, p. 149-150.

${ }^{33}$ Segundo José M. de Carvalho, a cobrança de impostos de importação e exportação era o que de fato alimentava os cofres imperiais e, apesar de muitas discussões políticas para suspendê-los e, assim, dinamizar o comércio, constituíam-se na forma mais fácil e eficiente de arrecadação devido à falta de agentes para a cobrança de outros tipos de taxação (como a per capita ou imposto territorial rural) e porque os "resultados eram imediatos e o contribuinte não percebia que estava pagando". CARVALHO, José Murilo de. A construção da ordem: teatro de sombras. Rio de Janeiro, Civilização Brasileira, 2003. p. 269. 
despachos de mercadorias, além de sofrer uma série de hostilidades, acabava contribuindo para o crescimento do contrabando "tradicional", já que impossibilitados de fazê-lo por dentro da Alfândega, os comerciantes viam-se obrigados a contrabandear pela fronteira desguarnecida, na calada da noite, munidos de bandos armados para escoltar as mercadorias. Portanto, independente de como chegava a ação do estado nas suas bordas territoriais, ela não é desprezível ou inexistente e desempenha funções concretas no cotidiano desse contexto fronteiriço. Nesse sentido, poder-se-ia mencionar ainda que a licença desfrutada pela Alfândega de Uruguaiana sofreu contenções quando o Estado julgou que o grau de autonomia daquela repartição pública havia extrapolado a transgressão consentida. A Alfândega de Uruguaiana sofreu pelo menos duas vezes a instalação de Comissões de fiscalização cujo objetivo era avaliar a probidade dos procedimentos dos funcionários daquela repartição, uma em 1857 e outra em $1861 .{ }^{34}$ Nenhuma delas foi bem recebida pela comunidade comerciantes local conforme discussões travadas nas correspondências da Câmara Municipal endereçadas ao Presidente da Província. 35

Outra situação exemplar de fronteira, que compreende sujeitos valendo-se das brechas oferecidas pela justaposição de soberanias e demonstra a ação do estado nas margens, coloca-se em torno da manutenção da escravidão e da ação dos sedutores de escravos nesse contexto. A escravidão na região de fronteira com países platinos contém um aspecto peculiar significativo ao considerarmos a existência de uma explícita incompatibilidade legal justaposta pelo limite político: enquanto as legislações do Estado Oriental e das Províncias do Rio da Prata estabeleciam a abolição da escravidão em seus territórios ${ }^{36}$, o Império brasileiro sustentou do seu lado a manutenção da escravidão até 1888. A efetividade ou não das leis, ou com quais restrições essa abolição da escravidão foi desfrutada nos países platinos, são

\footnotetext{
${ }^{34}$ APERS. Poder Judiciário. Cível e Crime. Processos Crime. Uruguaiana. Maço 62, no 2402, ano 1857. APERS. Poder Judiciário. Cível e Crime. Processos Crime. Uruguaiana. Maço 64, nº 2470, 1862. Relatório da Comissão de Inspeção da Alfândega de Uruguaiana de 1861.

${ }^{35}$ Ver: THOMPSON FLORES, Mariana F. da C. Crimes de fronteira... Op. Cit. p.183-190.

${ }^{36}$ É comum, na historiografia que se dedica ao tema das fugas de escravos pelas fronteiras do sul do Império ou às ações de liberdade que se valiam da fronteira, adotar a data de 15 de dezembro de 1842 para a abolição da escravidão no Estado Oriental e 4 de fevereiro de 1813, ou o decreto da Constituição de 1853, para a abolição nas Províncias do Rio da Prata. Contudo, nem as datas consideradas para as abolições estão de todo corretas, nem suas vigências garantiram liberdade aos escravos fugidos. A cronologia das leis abolicionista nesses países vizinhos foi mais complexa e menos definitiva do que em geral se atribui. Ver: GARAVAGLIA, Juan Carlos. El papel económico de la esclavitud en una sociedad no esclavista: el Río d la Plata, 1750-1860. 2009. Texto inédito. ISOLA, Ema. La esclavitud en el Uruguay: desde sus comienzos hasta su extinción (1743-1852). Publicación de la Comisión Nacional de Homenaje del sesquicentenario de los hechos históricos de 1825, 1975.
} 
questões fundamentais que esclarecem uma série de matizes dos episódios de fuga de escravos do Brasil pela fronteira, tornando-os bem mais complexos do que simplesmente possíveis de serem compreendidos como fugas em direção à liberdade, porém, não se pode desprezar o fato de que havia um meio legal de se acessar o estatuto de livre através da fuga, e isso, por si só, distingue as fugas de escravos nesse espaço de fronteira de outras empreendidas em outros lugares.

Do encontro dessa contraposição entre leis na fronteira se valiam os fronteiriços que dela podiam se beneficiar. Assim como escravos fugiam e buscavam liberdade e abrigo (frequentemente nas fileiras militares) no outro lado da fronteira, livres e libertos agiam como sedutores e também se beneficiavam ganhando pela prestação de seu serviço de atravessamento clandestino de negros que procuravam livrar-se da escravidão. A fuga de escravos em si, bem como, a sedução deles, não eram considerados crimes, portanto, teoricamente não eram passíveis de serem julgadas. Contudo, jurisprudências de tendência marcadamente escravistas permitiram que por muitos anos essas ocorrências figurassem como crimes sendo facilmente encontrados processos crimes de fugas de escravos (mascaradas de tentativas de levantes e insurreições) e de sedução de escravos (mascaradas de tentativas de roubo de escravos) ${ }^{37}$.

Os sedutores de escravos eram pessoas livres ou libertas que atuavam persuadindo escravos a fugir do domínio de seus senhores e seguir com eles, sedutores, para o outro lado da fronteira onde, certamente, prometiam que teriam uma vida melhor. Ser "vaqueano", exímio conhecedor do trajeto que seria percorrido durante a fuga, era condição obrigatória aos sedutores. Um sedutor sem essa habilidade não teria função alguma. Oferecer meios para a fuga, como cavalos, esconderijo, alimentação, também figuravam entre os serviços oferecidos pelos sedutores. Nesse sentido, é praticamente certo que os sedutores cobravam de alguma maneira o serviço que prestavam. Embora não se tenha encontrado nenhuma referência explícita nesse sentido, seria inviável pensar que os sedutores se ocupavam de uma tarefa de risco sem ganhar nada em troca.

\footnotetext{
${ }^{37}$ Em 1837, o decreto 138, do dia 15 de outubro, tornou extensivo ao delito de furto de escravos as penas e mais disposições estabelecidas para o delito de roubo. Tal decreto serviu de argumento para que diversos advogados tentassem enquadrar os "crimes" de sedução de escravos como roubo ou furto. Decreto Imperial n ${ }^{\circ} 138.15$ de outubro de $1837 . \quad$ Disponível em: http://www.camara.gov.br/Internet/InfDoc/conteudo/colecoes/Legislacao/Legimp-23/Legimp 23. 12.pdf Acesso em: 1 de dezembro de 2010.
} 
Muitas vezes, as cooperações informais entre as repartições policiais e militares de ambos os lados, e das redes sociais que atravessavam a fronteira colocavam o escravo fugido em uma condição sensível, já que poderia ser delatado e entregue às autoridades do lado imperial, ou capturado por alguém contratado por seu antigo senhor para este serviço. A fim de exercer maior autoridade nesses assuntos, tratados eram assinados visando padronizar as ações por parte do Estado. Em 1838, a Província de Corrientes declarou reconhecer os direitos de propriedade dos senhores brasileiros sobre seus escravos que entrassem fugidos naquele território permitindo que fossem capturados e retornados ao Brasil. $3^{8}$

Em 1848, outro tratado de extradição de escravos fugidos foi assinado com Províncias do Rio da Prata, o qual deveria incluir a Província de Corrientes, o que aponta para uma possível não implementação daquele acordo anterior. ${ }^{39}$ No ano antecedente, outro acordo foi assinado, entre Império do Brasil e Estado Oriental, com a mesma finalidade: reclamar escravos fugidos para aquele território, e sabe-se que foi muito em função destes tratados de extradição que listas foram organizadas, entre 1848 e 1850, para que senhores pudessem relacionar seus escravos que haviam fugido. 40

Houve também o conhecido Tratado de 12 de outubro de 1851, assinado entre Brasil e Estado Oriental, ao final da Guerra Grande, que contemplava em uma de suas partes um acordo de extradição de escravos fugidos do Brasil para aquele país. ${ }^{41}$ Finalmente, em 14 de dezembro de 1857, o Império do Brasil e a Confederação Argentina igualmente assinaram um tratado que previa a extradição de escravos fugidos. 42

\footnotetext{
${ }^{38}$ Lei de Corrientes do ano de 1835 decretando a devolução dos escravos fugidos do Brasil. In: BRASIL. Ministério das Relações Exteriores. Relatório do Ministro das Relações Exteriores, 1857. Anexo E, n. 18. p. 44.

${ }^{39}$ PETIZ, Silmei de Sant'Ana. Buscando a liberdade: as fugas de escravos da província de São Pedro para o além-fronteira (1815-1851). Passo Fundo: Editora da UPF, 2006. p. 64.

${ }^{40}$ AHRGS. 1850 - Rio Grande do Sul. Relação e descrição dos Escravos (por proprietários) fugidos para Entre Rios, Corrientes, Estado Oriental, República do Paraguai e outras províncias brasileiras. Estatística. Documentação Avulsa. Maço 1. AHRGS. Sem data. Serra do Caverá. Relação de escravos de José Maria de Sousa fugidos para Cisplatina. Estatística. Documentação Avulsa. Maço 2.

${ }^{41}$ Tratado de 12 de outubro de 1851. In: Tratados y Convenios Internacionales - suscritos por Uruguay en el periodo mayo de 1830 a diciembre de 1870. República Oriental del Uruguay. Secretaria del Senado Documentación y Antecedentes Legislativos. Montevideo, 1993. Tomo 1. OLIVEIRA, José Cardoso de. Actos Diplomáticos do Brasil. Brasília: Editora do Senado Federal, 1997. Tomo I.

${ }^{42}$ Tratado Império do Brasil e Confederação Argentina. 14/12/1857. In: BRASIL. Ministério das Relações Exteriores. Relatório do Ministro das Relações Exteriores, 1857. Anexo E, nº 13, p. 36.
} 
Contudo, independentemente da vigência dos tratados, seria de se esperar que os poderes locais continuassem encaminhando a resolução (ou não) dessas questões à sua maneira nesse delicado ajuste com o poder institucional.

Sobre o acordo de 1847 com o Estado Oriental, os vereadores de Alegrete e Uruguaiana, respectivamente em 4 e 19 de fevereiro de 1848, acusaram o recebimento da circular encaminhada pela presidência da província, com data de 27 de novembro de 1847 , onde constava a forma pela qual se deveriam reclamar os escravos que haviam fugido para o Estado Oriental, bem como informavam terem-na feito pública em todos os Termos. 43 Bastou pouco tempo, no entanto, para que começassem a ser encaminhadas reclamações a respeito da inefetividade do referido acordo.

Em carta dirigida ao delegado de polícia, Joaquim dos Santos Prado Lima, em 27 de abril de 1848, o proprietário de escravos Lino Antonio da Silva Caldeira remeteu sua queixa sobre o não cumprimento do acordo de extradição de escravos fugidos.

\begin{abstract}
"Transmito para conhecimento de V.S. que partindo eu no dia 6 ao corrente mez desta Villa, cheguei a Povoação do Salto na Província Oriental a 12 do mesmo, alli aprezentei ao Comandante Militar daquela praça o Coronel Lucas Pires, a reclamação por V.S. feita do escravo de minha propriedade de nome Januário, a qual o sobredito Coronel não se dignou ler a pretexto de que o escravo tinha seguido no dia 8 , como de facto, com outros escravos de propriedade brasileiras, remettidos no dia 19 de Março p.p. pelo Coronel Diogo Lamas, para as forças do General Oribe no [ilegível] e me afirmou também que ainda quando alli estivefse o meu ou outros qualquer nenhum effeito produziria a sobredita reclamação, por ifso que as ordens que a respeito tinha a tanto o authorizavão." "Então submeti hum meo requerimento ao qual anexando a mesma reclamação, tão pouco se dignou diferir pela razão acima allegada, e apesar de que eu lhe apresentafse a circular da Presidência desta província, de 27 de Novembro, tive em resposta que a mesma era só effectiva no território desta Província."44
\end{abstract}

A mesma carta foi remetida pelo mencionado Delegado de Polícia às instâncias superiores, no caso o Chefe de Polícia Dr. Manoel José de Freitas Travassos Filho, relatando o ocorrido e informando que o próprio delegado também havia enviado

\footnotetext{
${ }^{43}$ AHRGS. Câmara Municipal. Alegrete. Caixa 2. Maços 3,4. Ano 1848. Câmara Municipal. Uruguaiana. Caixa 182. Maços 336. Ano 1848.

${ }^{44}$ AHRGS. Alegrete. Polícia. Delegacia. Correspondência Expedida. Maço 1. Ano 1848. Grifo meu.
} 
cartas reclamatórias às autoridades da campanha oriental, Coronel Diogo Lamas e Coronel Lucas Pires, todavia, sem efeito. 45

$\mathrm{Na}$ "Relação escravos fugidos de 1850" 46 constam 13 escravos que, sem sucesso, já haviam sido reclamados, sendo que, em um caso em que cinco escravos fugidos eram reclamados, foram pedidos pelas autoridades orientais ao senhor dos cativos cem patacões por cada um dos escravos que fossem entregues. Essa situação demonstra uma prática ilegal, já que recompensas particulares não estavam previstas nos acordos, tampouco a autonomia dos poderes locais no cumprimento, ou não, desses tratados.

A partir de meados do século XIX, muito em função da circular imperial de 2 de julho de 1856 que declarava que todos os escravos residentes em países estrangeiros, ou vindos do exterior, que entrassem no território do Império deveriam ser colocados em liberdade não podendo serem entregues aos seus antigos senhores, cuja base jurídica era a lei de 7 de novembro de 1831, que declarava livres todos os escravos que a partir daquela data entrassem no Brasil, a ação e os limites do estado ficam mais ainda em evidência no encaminhamento de questões referentes a escravidão na fronteira.

No dia 30 de agosto, o delegado de polícia de Alegrete, Venâncio José Pereira, enviou ao presidente da província um inventário de questionamentos sobre a (in)viabilidade daquela circular em uma Freguesia como a de Alegrete que estava "sobre a linha divisória com o Estado Oriental, cuja divisão é uma estrada de carretas em distância de uma quadra, pouco mais ou menos, das ultimas casas da mesma freguesia". Dessa forma, o delegado "luctava com as seguintes duvidas":

\footnotetext{
" $1^{\mathrm{a}}$ - Se devem ser postos em liberdade quaesquer escravos, que, por qualquer circunstância passem além da mesma linha devisória, mesmo atraz de animaes, que succedem disparar e passar para o Estado visinho.

$2^{\mathrm{a}}$ - Se está no mesmo caso qualquer escravo de proprietários cujas Fazendas estão parte no Brasil e parte no referido Estado Oriental.
}

\footnotetext{
45 Ibidem.

${ }^{46}$ AHRGS. 1850 - Rio Grande do Sul. Relação e descrição dos escravos (por proprietários) fugidos para Entre Rios, Corrientes, Estado Oriental, República do Paraguai e outras províncias brasileiras. Estatística. Documentação Avulsa. Maço 1. AHRGS. Sem data. Serra do Caverá. Relação de escravos de José Maria de Sousa fugidos para Cisplatina. Estatística. Documentação Avulsa. Maço 2.
} 
$3^{\mathrm{a}}$ - E finalmente, se estão no mesmo goso os escravos que estando ali contratados voltem, ou passem para o Brasil: rogo pois a V. Exca se digne solve-las, visto como esta delegacia, pela transcendência do assumpto, não se crê autorizada para o fazer".47

Não tivemos acesso às respostas oficiais a essas intrigantes perguntas que refletem perfeitamente o quão complicado era aplicar resoluções oficiais onde diferentes soberanias atuavam quase que no mesmo espaço. Contudo, ao lado de cada pergunta, no mesmo documento, estão escritas a lápis as palavras "Não", "Não" e "Sim", respectivamente para o primeiro, segundo e terceiro questionamento. Considerando que as respostas tenham sido de fato essas, elas parecem bastante razoáveis, e até viáveis, de serem aplicadas no contexto da fronteira. O contrário provavelmente seria impraticável.

A partir de então a documentação começa a ser tomada por casos de processos de manutenção de liberdade de escravos que viviam cotidianamente esse tipo de situação relatada pelo delegado de polícia de Alegrete. O encaminhamento dos processos de sedução de escravos também muda nesse contexto passando a se valer do fato de que o ato de seduzir escravos para fuga não era considerado crime e a rigor tampouco podia ser imputado como crime de roubo, passando a serem frequentes sentenças do tipo:

\begin{abstract}
"não tinha intenção de tornal-a sua propriedade e nem também a tirava para outro, visto como a sua intenção era levar esses escravos a República do Uruguay a fim de recuperarem sua liberdade que o senhor lhes negava portanto e pelo mais que dos autos consta absolvo o réu da acusação que lhe foi imputada." 48
\end{abstract}

Percebe-se que o recurso da fronteira é um dado colocado a todos os fronteiriços, embora esse recurso não se coloque de maneira uniforme para esses sujeitos, mas de acordo com seus posicionamentos considerando que "pessoas situadas em posições diferentes podem acumular experiências particulares e lançar mão de diferentes esquemas de interpretação, ou seja, podem viver juntas, mas em mundos diferentemente construídos”.49 As legislações conflitantes, portanto, deixavam a brecha para a ação dos fronteiriços que diariamente manejavam essas

\footnotetext{
${ }^{47}$ AHRGS. Alegrete. Polícia. Delegacia. Correspondência Expedida. Maço 1, Ano 1856.

${ }^{48}$ APERS. Poder Judiciário. Cível e Crime. Processos Crime. Uruguaiana. Caixa 314. nº 2604. 1870.

${ }^{49}$ BARTH, Fredrik. Por um maior naturalismo na conceptualização das sociedades. In: $O$ guru, o iniciador $e$ outras variações antropológicas. Rio de Janeiro: Contra Capa Livraria, 2000. p. 176.
} 
situações a seu modo, acomodando-se entre as soberanias justapostas e as redes transfronteiriças de que dispunham. Nesse delicado concerto entre a ação do Estado e as redes sociais locais que atravessavam a fronteira, pode-se dizer que nenhum se sobrepunha. Ambos atuavam concomitantemente e, não raro, um operava através do outro mutuamente.

Nesse sentido, parece acertado considerar o espaço de fronteira como lugar de integração social e econômica, onde o cotidiano promove a interação das comunidades independente de qualquer projeto ou respaldo institucional, mas onde também os estados, respeitando contingências próprias a esse espaço, se fazem representar demarcando-se permanentemente através de burocracias e instituições específicas. Para além disso, o grau de autonomia local influi tanto para beneficiar o distanciamento das normatizações do Estado quanto para que agentes do próprio Estado operem de forma extraoficial na manutenção das lógicas daquele espaço. A fronteira, dessa forma, não é um simples cenário onde as relações e, nesse caso, os crimes acontecem, mas é uma agente que oferece recursos e elementos incontornáveis nas estratégias cotidianas de seus habitantes e presentes em todos os âmbitos de suas vidas.

\section{Fontes}

Arquivo Histórico do Rio Grande do Sul (AHRGS). Câmara Municipal. Alegrete. Caixa 2. Maços 3,4. Ano 1848. Câmara Municipal. Uruguaiana. Caixa 182. Maços 336. Ano 1848.

AHRGS. Alegrete. Polícia. Delegacia. Correspondência Expedida. Maço 1. Ano 1848.

AHRGS. 1850 - Rio Grande do Sul. Relação e descrição dos escravos (por proprietários) fugidos para Entre Rios, Corrientes, Estado Oriental, República do Paraguai e outras províncias brasileiras. Estatística. Documentação Avulsa. Maço 1. AHRGS. Sem data. Serra do Caverá. Relação de escravos de José Maria de Sousa fugidos para Cisplatina. Estatística. Documentação Avulsa. Maço 2.

AHRGS. Relatório do Presidente da Província do Rio Grande do Sul. A-7.03. 1856.

AHRGS. Alegrete. Polícia. Delegacia. Correspondência Expedida. Maço 1, Ano 1856. 
Arquivo Público do Estado do Rio Grande do Sul (APERS). Poder Judiciário. Cível e Crime. Processos Crime. Municípios: Alegrete, Uruguaiana, Santana do Livramento e Quaraí. Período: 1845-1889.

AVÉ-LALLEMANT, Robert Christian Bertold. Viagem pelo sul do Brasil no ano de 1858. Belo Horizonte: Editora Itatiaia, 1980.

Código Criminal do Império do Brazil de 1830. Rio de Janeiro: Livraria Popular. 1877.

Código de Processo Criminal de 1832. Disponível em http://www.planalto.gov.br/ccivil_03/leis/LIM/LIM-29-11-1832.htm

Decreto Imperial $\mathrm{n}^{\mathrm{o}}$ 138. 15 de outubro de 1837. Disponível em: http://www.camara.gov.br/Internet/InfDoc/conteudo/colecoes/Legislacao/Legim p-23/Legimp 23._12.pdf

DREYS, Nicolau. Notícia descriptiva da Província do Rio Grande de São Pedro do Sul. Porto Alegre: Instituto Estadual do Livro, 1961.

Lei de Corrientes do ano de 1835 decretando a devolução dos escravos fugidos do Brasil. In: BRASIL. Ministério das Relações Exteriores. Relatório do Ministro das Relações Exteriores, 1857. Anexo E, n. 18. p. 44.

OLIVEIRA, José Cardoso de. Actos Diplomáticos do Brasil. Brasília: Editora do Senado Federal, 1997. Tomo I.

Relatório do Presidente da Província João Pedro Carvalho de Moraes. 1875. Disponível em: http://www.seplag.rs.gov.br/upload/1875_Joao_Pedro_Carvalho_de_Moraes_Fa lla.pdf

Tratado de 12 de outubro de 1851. Tratado de Comercio e Navegación. In: Tratados y Convênios Internacionales - suscritos por Uruguay en el período mayo de 1830 a diciembre de 1870. República Oriental del Uruguay. Secretaria del Senado Documentación y Antecedentes Legislativos: Montevideo, 1993. Tomo 1.

Tratado Império do Brasil e Confederação Argentina. 14/12/1857. In: BRASIL. Ministério das Relações Exteriores. Relatório do Ministro das Relações Exteriores, 1857. Anexo E, $\mathrm{n}^{\circ}$ 13, p. 36.

\section{Referências Bibliográficas}

BARRIERA, Darío (comp.). Justicias y fronteras: estudios sobre historia de la justicia em el Río de la Plata: siglos XVI-XIX. Murcia, Universidad de Murcia, Servicio de Publicaciones, Red Columnaria, 2009. 
BARTH, Frederik. Process and Form in Social Life: Selected Essays of Fredrik Barth. Volume I. London, Routlege \& Kegan Paul, 1981.

O guru, o iniciador e outras variações antropológicas. Rio de Janeiro: Contra Capa Livraria, 2000.

BORUKI, Alex; CHAGAS, Karla; STALLA, Natália. Esclavitud y trabajo: un estudio sobre los afrodescendentes en la frontera uruguaya: 1835-1855. 2. ed. Montevideo, Uruguay: Mastergraf, 2009.

CARVALHO, José Murilo de. A construção da ordem: teatro de sombras. Rio de Janeiro, Civilização Brasileira, 2003.

CHIARAMONTE, José Carlos. Mercaderes del litoral: economía y sociedade em la Provincia de Corrientes, primera mitad del siglo XIX. Buenos Aires, Fondo de Cultura Económica, 1991.

CLEMENTI, Hebe. La frontera en la América (Argentina / Brasil). Buenos Aires, Leviatan, 1988.

FARINATTI, Luís Augusto E. Confins Meridionais: famílias de elite e sociedade agrária na Fronteira Sul do Brasil (1825-1865). Tese de Doutorado - PPGHISUFRJ, Rio de Janeiro, 2007.

FARINATTI, Luís Augusto E.; THOMPSON FLORES, Mariana F. da C. "A fronteira manejada: apontamentos para uma história social da fronteira meridional do Brasil (século XIX)". In: HEINZ, Flávio (org.). Experiências nacionais, temas transversais: subsídios para uma história comparada da América Latina. São Leopoldo, Oikos, 2009.

FRADKIN, Raúl. "La experiencia de la justicia: estado, propietarios y arrendatários en la campaña bonaerense”. In: La fuente judicial en la construcción de la memoria. Buenos Aires, Universidad Nacional de Mar del Plata, 1999. p. 145-188.

GARAVAGLIA, Juan Carlos.

-Poder, conflicto y relaciones sociales: el Río de la Plata, XVIII - XIX. Rosario, Homo Sapiens Ediciones, 1999.

-El papel económico de la esclavitud en una sociedad no esclavista: el Río d la Plata, 1750-1860. 2009. Texto inédito.

GARCIA, Graciela Bonassa. O domínio da terra: conflitos e estrutura agrária na campanha rio-grandense oitocentista. Dissertação de Mestrado, UFRGS, Porto Alegre, 2005.

GIL, Tiago Luís. Infiéis transgressores: os contrabandistas da fronteira (1760-1810). Dissertação de Mestrado - Rio de Janeiro, IFCS/UFRJ, 2002. 
GRIMSON, Alejandro. La Nación en sus límites: contrabandistas y exilados en la frontera Argentina-Brasil. Barcelona, Editorial Gedisa, 2003.

GRINBERG, Keila. As fronteiras da escravidão e da liberdade no sul da América. Rio de Janeiro, 7 Letras, 2013.

GUAZZELLI, Cesar Augusto Barcellos. O horizonte da Província: A República RioGrandense e os caudilhos do Rio da Prata (1835-1845). Porto Alegre, Linus, 2013.

HAMEISTER, Martha Daisson. O Continente do Rio Grande de São Pedro: os homens, suas redes de relações e suas mercadorias semoventes. Rio de Janeiro, PPGHIS/UFRJ, 2002.

ISOLA, Ema. La esclavitud en el Uruguay: desde sus comienzos hasta su extinción (1743-1852). Publicación de la Comisión Nacional de Homenaje del sesquicentenario de los hechos históricos de 1825, 1975.

LOPES, Maria Aparecida de S. De costumbres y leyes: abigeato y derechos de propiedad en Chihuahua durante el Porfiriato. México, D.F, El Colegio del México; Centro de Estudios Históricos, 2005.

MARTINS, Rui Cunha. O método da fronteira: radiografia histórica de um dispositivo contemporâneo (matrizes ibéricas e americanas). Coimbra, Edições Almedina, 2008.

MAYO, Carlos (org.). Vivir en la frontera: la casa, la pulpería, la escuela (18701870). Buenos Aires, Editorial Biblos, 2000.

MEDRADO, Joana. "Terra, laço e moirão": relações de trabalho e cultura política na pecuária (Geremoabo, 1880-19oo). Dissertação de Mestrado, Universidade Estadual de Campinas, Campinas, 2008.

MEDRANO, Lilia Inês Zanotti de. A livre navegação dos Rios Paraná e Uruguay: uma análise do comércio entre o Império Brasileiro e a Argentina (1852-1889). Tese de Doutorado, USP, São Paulo, 1989.

MOUTOUKIAS, Zacarias. Contrabando y control colonial en el siglo XVII: Buenos Aires, el Atlántico y el espacio peruano. Buenos Aires, Centro Editor de la América Latina, 1987.

OSÓRIO, Helen. O império português no sul da América: estancieiros, lavradores e comerciantes. Porto Alegre, Editora da UFRGS, 2007.

PETIZ, Silmei de Sant'Ana. Buscando a liberdade: as fugas de escravos da província de São Pedro para o além-fronteira (1815-1851). Passo Fundo: Editora da UPF, 2006.

SCHMIT, Roberto. Ruina y resurrección en tiempos de guerra: sociedad, economía y poder en el oriente entrerriano posrevolucionario: 1810-1852. Buenos Aires, Prometeo Libros, 2004. 
SLATTA, Richard W. Bandidos: The Varieties of Latin American Banditry. New York: Greenwood Press, 1987.

SODRÉ, Elaine L. de Vargas. A disputa pelo monopólio de uma força (i)legítima: Estado e Administração Judiciária no Brasil Imperial (Rio Grande do Sul, 18331871). Tese de Doutorado, PPGH-PUCRS, Porto Alegre, 2009.

SOUZA, Suzana Bleil de \& PRADO, Fabrício Pereira. "Brasileiros na fronteira uruguaia: economia e política no século XIX”. In: GRIJÓ, GUAZZELLI, KÜHN \& NEUMANN (org.). Capitulos de História do Rio Grande do Sul: Texto e Pesquisa. Ed. Da Universidade/ UFRGS, 2004.

THOMPSON FLORES, Mariana F. da C. Crimes de fronteira. A criminalidade na fronteira meridional do Brasil (1845-1889). Porto Alegre, EDIPUCRS, 2014.

VARGAS, Jonas M. Entre a paróquia e a Corte: a elite política do Rio Grande do Sul (1850-1889). Santa Maria, Ed. da UFSM, 2010.

VOLKMER, Márcia S. "Onde começa ou termina o território pátrio": os estrategistas da fronteira: empresários uruguaios, política e a indústria do charque no extremo oeste do Rio Grande do Sul (Quaraí, 1893-1928). Dissertação de Mestrado, UNISINOS, São Leopoldo, 2007.

YOUNGER, Joseph. "Corredores de comércio e salas de justiça: lei, coerção e lealdade nas fronteiras do Rio da Prata”. Revista Aedos, v. 1, n. 1, p. 290-311, 2008. 